\title{
No limits in the future of sports and exercise medicine!
}

\author{
John Bjørneboe (10 ,1,2 Arnlaug Wangensteen ${ }^{2,3}$
}

It is been almost 18 months since the COVID-19 outbreak closed the borders and forced us to change the way of communicating and interacting across our communities. But despite that we have been limited in terms of physical assemblies, it appears to be no limits in how to keep ourselves connected through virtual communication. And some changes over the last year are probably here to stay, such as digital patient communication and broadcasting of conferences to increase the reach of the conference. In Norway, our yearly SEM conference was digitalised last fall, increasing the number of participants from 500 to 1000 . In addition, the sessions were available online after the conference. This year, we are happy to announce that the conference will be held on site in Oslo 29-31 October (figure 1). However, due to last year's success, the conference will also be available for virtual participation, mirroring that there are no limits in the future of SEM. This year's theme is physical activity and sports medicine in children, adolescents and young adults. Romain Seil will hold a keynote lecture on children and adolescents with a global focus on sport participation, sports injuries and injury prevention; Ulf Eklund will talk about physical activity and health, and Michael Rathleff will present updated evidence on musculoskeletal pain in children and adolescents.

We are proud to present to you the yearly Norwegian Sports and Exercise Medicine Society's issue of BJSM. Over the last 5-10 years, parasport has been a key session on our yearly conference, and we believe that the SEM community should be an inclusive society focusing on equality regardless. We are therefore honoured to include the IOC consensus statement on recording and reporting of data in para sport in this

\footnotetext{
'Department of Physical Medicine and Rehabilitation, Oslo University Hospital, Oslo, Norway

${ }^{2}$ Oslo Sports Trauma Research Center, Oslo, Oslo, Norway

${ }^{3}$ Norsk Idrettsmedisinsk Institutt, Oslo, Norway
}

Correspondence to John Biørneboe, Department of Physical Medicine and Rehabilitation, Oslo University Hospital, Oslo, Norway; john.bjorneboe@gmail.com issue (see page 1068). These athletes are truly role models in showing that there are no limits if we choose to focus on abilities and possibilities instead of disabilities.

In Sports and Exercise Medicine context is key, thus we would like to highlight the editorial regarding Realist synthesis in SEM, and the need for implementation science (see page 1064). Methods matter not only for the researcher and authors, therefore we have included an editorial with updated guidance for reviewing papers in BJSM (see page 1063).

The first step of injury prevention research is to establish the extent of the problem. In football medicine, the Football Research Group has provided high quality insights on injury epidemiology research through their UEFA Elite Club Injury Study over the last decade. For all involved in football and football medicine, it is encouraging to see that over the last 18 years, injury incidence for both matches and training has decreased and the player availability for training and match play increased (see page 1084). One effective injury preventive measure over the last decade is the Copenhagen Adduction exercise, and a key element is the training load. Ishøi and Thorborg promote training volume as the sole progression variable for both eccentric strength development and reduce adductor injuries (see page 1066).

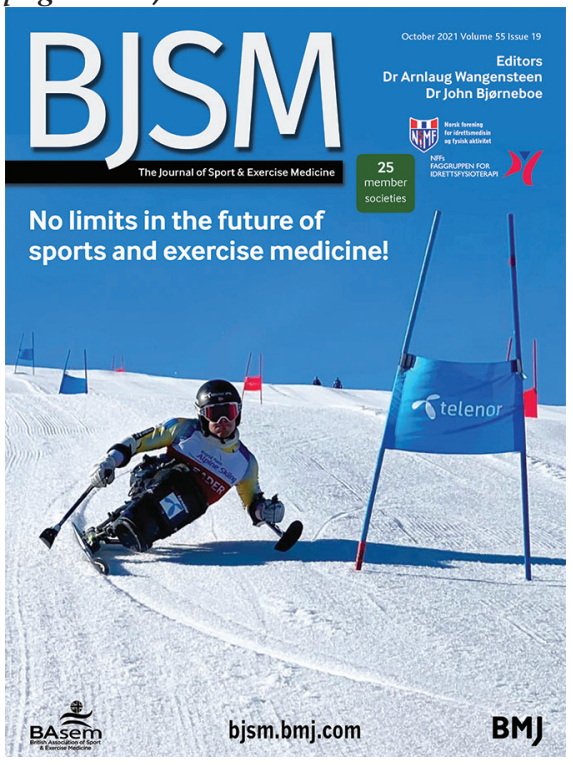

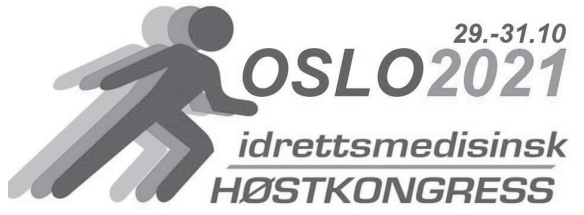

Figure 1 Norwegian Sports Medicine Conference 2021.

Despite relatively low COVID-19 rates in Norway, amateur senior football training and match play was paused between March 2020 and June 2021 due to the COVID-19 situation. However, a study from Qatar, a country with high infections rates, found a limited risk for SARS-CoV-2 infection and severe illness when preventive measures are in place (see page 1092). In addition, physical inactivity is associated with an increased risk for severe COVID-19 outcomes (see page 1099).

Another mainstay in injury monitoring is the IOC injury surveillance system in Olympics and Paralympics, where athletes in martial arts on average suffered an injury every 2.1 hours of competition (see page 1077). An athlete that was aiming to participate in the summer Olympics in Tokyo is the Norwegian judo athlete Madelene Rubinstein. However, as you will read in the patient voice she struggled with breathing problems, interpreted as asthma or just low fitness level. After realising that neither asthma medication nor harder cardio training solved her problem, she was further examined, and her problem was identified as exercise-induced laryngeal obstruction (EILO). EILO is a common cause of breathing problems and seems to occur more often in the athletic populations, and one should keep in mind that this also affects athletes not involved in endurance sports.

Finally, on behalf of the Norwegian Sports Medicine society, we are looking forward to seeing you all again in the near future. Maybe we will already meet virtually or physically in Oslo in November? No limits in the future of sports and exercise medicine!

Acknowledgements The athlete on the cover is the Norwegian alpine skier and Paralympic champion Jesper Saltvik Pedersen. Thanks to Jesper for providing us the image, which has been obtained by permission. Photographer: Synne Sofie Stangeland.

Contributors JB and AW contributed equally to the writing of this paper. 


\section{Warm up}

Funding The authors have not declared a specific grant for this research from any funding agency in the public, commercial or not-for-profit sectors.

Competing interests None declared.

Patient consent for publication Not required.

Provenance and peer review Commissioned; internally peer reviewed.
(C) Author(s) (or their employer(s)) 2021. No commercial re-use. See rights and permissions. Published by BMJ.

\section{(D) Check for updates}

To cite Bjørneboe J, Wangensteen A. Br J Sports Med 2021;55:1061-1062.
Accepted 29 July 2021

Br J Sports Med 2021:55:1061-1062. doi:10.1136/bjsports-2021-104826

\section{ORCID iD}

John Bjørneboe http://orcid.org/0000-0002-01148539 